\title{
Olabode Ibironke. Remapping African Literature.
}

Basingstoke: Palgrave Macmillan, 2018. 333 p. ISBN: 9783319692968.

$€ 103.99$

\section{Cédric Courtois}

\section{Q OpenEdition}

\section{Journals}

Electronic version

URL: https://journals.openedition.org/ces/1166

DOI: $10.4000 /$ ces. 1166

ISSN: 2534-6695

Publisher

SEPC (Société d'études des pays du Commonwealth)

\section{Electronic reference}

Cédric Courtois, "Olabode Ibironke. Remapping African Literature.", Commonwealth Essays and Studies [Online], 42.1 | 2019, Online since 20 December 2019, connection on 25 September 2021. URL: http:// journals.openedition.org/ces/1166 ; DOl: https://doi.org/10.4000/ces.1166

This text was automatically generated on 25 September 2021

\section{(c) $(1) \odot$}

Commonwealth Essays and Studies is licensed under a Licence Creative Commons Attribution - Pas d'Utilisation Commerciale - Pas de Modification 4.0 International 


\section{Olabode Ibironke. Remapping African Literature.}

Basingstoke: Palgrave Macmillan, 2018. 333 p. ISBN: 9783319692968. $€ 103.99$

Cédric Courtois

\section{REFERENCES}

Basingstoke: Palgrave Macmillan, 2018. 333 p. ISBN: 978331969 2968. €103.99

1 Remapping African Literature puts forth the links between literary aesthetics and publishing policies and reassesses literary criticism on African literature using an interdisciplinary approach to African literature, particularly through the use of archives, which constitute a central source for Ibironke's arguments. Until the publication of this timely study, these archives had not been published. They come in the form of private exchanges between African authors and Western publishers, namely from the Heinemann African Writers Series, a series of books published from 1962, which have enabled African writers to gain international visibility.

2 The "Re" in "Remapping" shows that Ibironke sets out to revise and rethink the reasons that have led to the construction of the canon of African literature until now. With his interest in archives, Ibironke is in line with critic - and former Professor at the University of Austin, Texas - Bernth Lindfors, and the latter's own fascination with archives which he has considered as material for literary criticism (amidst these archives, those of Amos Tutuola's The Palm-Wine Drinkard, kept at the University of Austin, Texas). The decision to keep Tutuola's archives in Texas, which serves as just one example to illustrate Ibironke's point, triggered the wrath of some of the firstgeneration African writers since, among other reasons, it constituted a continuation of colonial practices.

3 Ibironke shows how publishing and editing practices influenced textual production. By using the Marxist theory of dialectical materialism, which he applies to the Heinemann 
African Writers Series, Ibironke argues that African literature is a product of Western hegemonic culture. According to Ibironke, "[t]he production of African literature presents a unique problem space for African literary criticism that requires a study of institutional practices and effects that mediate and permeate texts, as well as texts' reflexivity on conditions of production and their capacity to transform institutional practices," hence a dialectical process, which he calls "auto-heteronomy." Among other things, Remapping African Literature puts to the fore African writers' "counter pressures" targeting the "producers of culture, [...] the institutions of literary production" (3). With the term "auto-heteronomy," Ibironke has in mind a form of reciprocity of effects whereby texts (and writers) seem to anticipate and therefore contribute to shaping the conditions of literary production. Ibironke goes against Roland Barthes' poststructuralist idea that the author is dead. On the contrary, the African writer is an essential agent in cultural production.

The book is composed of eight chapters (including the introduction and the conclusion). The Introduction starts off by announcing what will be at the core of Ibironke's study: "African writers are operators of postcolonial transformation" (1). This short introduction is efficient in that it clearly puts forth the main arguments that will be detailed at length in the rest of the book.

Chapter Two, entitled "The Commonwealth Impresario," delves into the key role and place of British publishers (among them, James Currey), and the power dynamics in the book industry. For Ibironke, it is clear that some decisions made in publishing houses in London had a huge impact on the content of African literature, later canonized by these very publishers. The latter contributed to giving shape to this literature, which may have been deprived of its original content and purpose, and this situation could have prevented some works from becoming canonical.

Chapter Three is aptly entitled "The Literary Scramble for Africa: Selection and the Practice of Hierarchies," and takes up the arguments presented in the second chapter. Ibironke exposes the Heinemann African Writers Series' publishing practices, which contributed to the mapping of African literature (Wole Soyinka referred to "the activities of British publishers as a 'second scramble for Africa'," 54). These practices clashed with the rising consciousness of African writers and, to a certain extent, their Bildungen as artists. Two main arguments are presented in this chapter: Ibironke points out Heinemann's "act of mapping" (61), which is intrinsically linked to "the political mapping of Africa by imperial and neo-colonial power" (61). Ibironke also shows how African writers claimed their respective autonomies vis-à-vis the Heinemann African Writers' Series.

7 The next three chapters ("The Seeds of the Series: Chinua Achebe and the Educational Publisher," "Wole Soyinka: The Pan-African Literary Practice," "Ngugi: Language, Publics, and Production") each focus on one specific master of African literature. Ibironke develops his central concept, "auto-heteronomy," thanks to which he analyses the works of Chinua Achebe, Wole Soyinka and Ngugi wa Thiong'o, and sheds light on their respective ideologies, which have often clashed. The Kenyan writer's role is particularly highlighted, and Ibironke clearly shows how he contributed to shaping the poetics and politics of African literature, namely by focusing on the decolonizing of African minds through language.

Chapter Eight, entitled "Conclusion: The Auto-Heteronomy of African Literature," insists on the importance of the autonomy of African writers. Ibironke also claims that 
Remapping African Literature makes it possible to put forth "the material agency of writers in exerting genuinely decolonizing counter-pressures to the forces of an apparatus that seeks to confine them" (305), therefore contributing to rewriting the Afro-pessimistic script about the continent: the concept of "auto-heteronomy" enables Ibironke to offer a more optimistic view of cultural production on the African continent.

Remapping African Literature is a major contribution. It is nevertheless surprising to notice that Ibironke refers to "African literature" in the singular; also worthy of note is his choice to study literature - or literatures? - written in English only, while his (decolonizing) approach could very well work for Lusophone, Francophone and, of course, Indigenous African literatures. One may also wonder about the androcentric approach adopted by Ibironke, who focuses on male writers only. Despite these limitations, this book remains an excellent study of the relationships between publishers and authors and how they have impacted literary production on the African continent.

\section{AUTHORS}

\section{CÉDRIC COURTOIS}

University of Paris 1 Panthéon-Sorbonne

Cédric Courtois teaches English at the University of Paris 1 Panthéon-Sorbonne. His PhD dissertation (2019) is entitled "Itineraries of a Genre. Variations on the Bildungsroman in Contemporary Nigerian Fiction" and he has published several articles and book chapters on this topic. His research interests include postcolonial literatures, refugee literature, decoloniality, transnationalism, transculturalism, ecopoetics, gender studies, mobility studies, and the ethics and aesthetics of violence in African literatures written in English. 